\title{
PI3K/Akt/mTOR Signaling Pathway and the Biphasic Effect of Arsenic in Carcinogenesis
}

\author{
Qiao Yi Chen ${ }^{1}$ and Max Costa $^{1}$ \\ Department of Environmental Medicine, New York University School of Medicine, Tuxedo, New York \\ Received February 22, 2018; accepted April 30, 2018
}

\section{ABSTRACT}

Arsenic is a naturally occurring, ubiquitous metalloid found in the Earth's crust. In its inorganic form, arsenic is highly toxic and carcinogenic and is widely found across the globe and throughout the environment. As an International Agency for Research on Cancer-defined class 1 human carcinogen, arsenic can cause multiple human cancers, including liver, lung, urinary bladder, skin, kidney, and prostate. Mechanisms of arsenic-induced carcinogenesis remain elusive, and this review focuses specifically on the role of the PI3K/AKT/mTOR pathway in promoting cancer development. In addition to exerting potent carcinogenic responses, arsenic is also known for its therapeutic effects against acute promyelocytic leukemia. Current literature suggests that arsenic can achieve both therapeutic as well as carcinogenic effects, and this review serves to examine the paradoxical effects of arsenic, specifically through the PI3K/AKT/mTOR pathway. Furthermore, a comprehensive review of current literature reveals an imperative need for future studies to establish and pinpoint the exact conditions for which arsenic can, and through what mechanisms it is able to, differentially regulate the PI3K/AKT/mTOR pathway to maximize the therapeutic and minimize the carcinogenic properties of arsenic.

\section{Introduction}

Arsenic is a naturally occurring, ubiquitous metalloid found in the Earth's crust. In its inorganic form, arsenic is highly toxic and carcinogenic and is widely found across the globe and throughout the environment. Along with natural corrosion of rocks and minerals, anthropogenic sources of contamination, such as burning fossil fuels, mining, and application of arsenical pesticides, further aggravate arsenic-elicited public health issues, which first gained recognition beginning in the 1990s. Today nearly 200 million people are exposed to arsenic at levels greater than the World Health Organization's recommended limit of 10 parts per billion (ppb). Startling levels of arsenic have been found around various regions around the world, including the French Mediterranean coastal areas, Bangladesh, China, United States, Mexico, and others (Chen and Costa, 2017). In the United States, excessive amounts of arsenic in drinking water have been found in the New England, Western, and Midwestern regions (Carpenter and

This work was supported by the following National Institute of Health (NIH) grants: ES000260-54, ES022935-05, ES023174-04, ES026138-03.

${ }^{1}$ Q.Y.C. and M.C. contributed equally to this work

https://doi.org/.10.1124/mol.118.112268.
Jiang, 2013). In fact, more than 70 countries documenting arsenic contamination have reported levels up to $5000 \mathrm{ppb}$ (Shankar et al., 2014). Arsenic is known to pollute the water system, but the route of exposure is not limited to drinking water. Adding to the extensity of arsenic's prevalence, toxic dust of this metalloid can be found in common occupational settings such as copper smelters and areas neighboring the smelter (Axelson et al., 1978; Enterline et al., 1987; Carpenter and Jiang, 2013).

High concentrations of arsenic can elicit rapid toxic effects resulting in death. As a matter of fact, arsenic is infamously known as the "poison of the kings." On the other hand, nonlethal doses of chronic arsenic exposure can elicit potent carcinogenic effects. As an International Agency for Research on Cancer-defined class 1 human carcinogen, arsenic can cause multiple human cancers, including liver, lung, urinary bladder, skin, kidney, and prostate (Naujokas et al., 2013). Chen et al. (2011) reported that at levels between 10 and $300 \mathrm{ppb}$, serious conditions such as cardiovascular and neurologic diseases, skin lesions, hepatic and renal dysfunctions have been reported. An estimated 100 million people are chronically exposed to more than $50 \mathrm{ppb}$ of arsenic via drinking water (Moon et al., 2012). Regarding the wide-

ABBREVIATIONS: AKT, protein kinase B; AP-1, activator protein 1; APL, acute promeylocytic leukemia; ATO, arsenic trioxide; EGFR, epidermal growth factor receptor; HCS-2/8, human chondrocyte cell; HIF-1, hypoxia-inducible factor 1 ; HIF-1a, hypoxia-inducible factor $1-\alpha$; HOS, human osteosarcoma cell; HT-29, human colorectal adenocarcinoma cell; HUC1, normal human bladder cells; mTOR, mammalian target of rapamycin; mTORC1, mTOR complex 1; PI3K, phosphoinositide 3-kinase; PIP2, phosphatidylinositol-3,4,5-triphosphate; PIP3, phosphatidylinositol-4,5bisphosphate; ROS, reactive oxygen species; S6K1, S6 kinase-1; TSC, tuberous sclerosis complex. 
range health effects of arsenic exposure, tremendous amounts of scientific efforts have been invested in elucidating the mechanisms of arsenic-induced toxicity and carcinogenicity. Although current studies suggest the mechanisms are manifold, this review focuses specifically on the role of the PI3K/AKT/mTOR, a prominent cellular signaling pathway, in arsenic-induced carcinogenesis.

\section{Potential Mechanisms of Arsenic-Induced Carcinogenicity}

The processes of cancer initiation, promotion, and progression are overwhelmingly complex, and arsenic-induced carcinogenesis may occur through multiple mechanisms. Current evidence suggests that arsenic works through both genotoxic and cytotoxic, as well as epigenetics pathways, which further complicates the quest to mitigate arsenic-associated diseases and cancers. Research suggests that reactive oxygen species (ROS) generated through arsenic metabolism can contribute to cancer initiation and promotion (Barchowsky et al., 1996; Liu and Jan, 2000; Lynn et al., 2000; Huang et al., 2004). The ROSs are effective at modifying the DNA by inducing basepair mutations, insertions, deletions, and so forth (Rossman et al., 1980; Huang et al., 2004). DNA damage of essential tumor suppressor genes can give rise to carcinogenesis. ROSs have also been suggested to disturb important cytoplasmic and nuclear signal transduction pathways, both of which are vital for controlling gene expression (Sen and Packer, 1996; Lander, 1997; Li et al., 1998; Huang et al., 2004).

Cellular responses to activation or inhibition of specific gene transcription are stimulated through extracellular signals transmitted through the cell plasma membrane, passed along a chain of intracellular signaling molecules to regulatory transcription factors, which consist of proteins that recognize specific DNA sequences and initiate transcription (Huang et al., 2004). Note that basal transcription, as well as endogenous stressor-induced transcription, can occur. In the case of malignant cell transformation, a variety of signaling pathways and transcription factors, such as activator protein 1 (AP-1) and $\mathrm{NF} \kappa \mathrm{B}$, regulate the expression of genes that carry out cell proliferation, differentiation, and transformation (Wang et al., 1996; Huang et al., 1999, 2004). Current evidence also suggests that arsenic can exert its carcinogenic effects through disrupting important signal transduction pathways (Snow, 1992; Huang et al., 1999, 2004). One prominent example is the PI3K/AKT/mTOR pathway. Because of the many important roles of PI3K, AKT, and mTOR in cell survival, cellular physiology, and pathologic alterations, perturbations of this pathway can elicit cancers of the breast, colon, neck, ovary, and lung (Levine, 2007; Bartholomeusz and GonzalezAngulo, 2012; Kandoth et al., 2013; Li and Wang, 2014; Guimaraes et al., 2015; Tai et al., 2017). Alterations in the PI3K/AKT/mTOR pathway can be caused by various factors, including genetic mutations, hepatitis $\mathrm{C}$ virus, chemical toxicants such as heavy metals, and physiologic products, including free fatty acids and interleukin (IL)-6 ( $\mathrm{Li}$ and Wang, 2014). Chemical toxicants-such as arsenic, mercury, cadmium, vanadate, and nicotine - can induce malignant cell transformation through the PI3K/AKT/mTOR pathway (Gao et al., 2002, 2004; West et al., 2003; Wang et al., 2009; Jing et al., 2012; Rauch et al., 2012; Li and Wang, 2014; Roy et al., 2014). Multiple studies demonstrate that this signaling cascade is often found disrupted after chronic arsenic exposure (Jiang and Liu, 2009; Carpenter et al., 2011; Carpenter and Jiang, 2013). This review provides a comprehensive perspective on arsenic-induced carcinogenesis and focuses on the PI3K/AKT/mTOR pathway.

\section{Phosphoinositide 3-Kinase}

Phosphoinositide 3-kinase (PI3K) activity can be activated by various growth factor receptors and oncogenes. In fact, elevated PI3K signaling is regarded as a distinct hallmark of cancer (Fruman et al., 2017). PI3K family members consist of heterodimeric enzymes and are divided into three major classes based on structure, function, and substrate specificity. In almost all tissue types studied to date, PI3K signaling has important implications in a variety of physiologic processes. Notably, PI3K family members are also involved in an extensive range of cellular regulatory processes, such as cell proliferation, migration, and metabolism (Fruman et al., 2017). Consequently, alterations in the PI3K signaling pathway can lead to a variety of human diseases, including diabetes and cardiovascular, neurologic, and immunologic disorders (Fruman et al., 2017). Furthermore, as demonstrated using cancer genomic analyses, PI3K gene mutations are frequently found in human tumors (Samuels et al., 2004).

Class $1 \mathrm{PI} 3 \mathrm{Ks}$ have the unique ability to catalyze the phosphorylation of phosphatidylinositol-4,5-bisphosphate (PIP2) into phosphatidylinositol-3,4,5-triphosphate (PIP3), a secondary messenger and mediator of PI3K activity, specific for the recruitment of cytoplasmic proteins to the endo- or plasma membranes (Rameh and Cantley, 1999; Czech, 2000). Studies have suggested that PIP3 is critical to PI3K-related oncogenicity, and elevated levels of PIP3 are frequently found in cancer cells; thus, class 1 , rather than 2 and 3 , is specifically linked to cancer development (Zhao and Vogt, 2008; Fruman et al., 2017). Four catalytic isoforms are in class 1: p110a, b, g, and d, encoded by PIK3CA, PIK3CB, PIK3CG, and PIK3CD, respectively. In general, class $1 \mathrm{PI} 3 \mathrm{Ks}$ are stimulated by various upstream activators, such as receptor-coupled tyrosine kinase, heterotrimeric $\mathrm{G}$ proteins, and small Ras-related GTPases (Fruman et al., 2017). In the event of receptorcoupled tyrosine kinase activation, two PI3K subunits, PI3KR1 (PI3K p85) and PI3KCA (PI3K p110), are recruited to form an active PI3K complex, which will then proceed to phosphorylate PIP2 to form PIP3 (Manning and Cantley, 2007). PI3K signaling is negatively regulated by lipid phosphatases, such as tumor suppressor phosphatase and tensin homolog, which can rapidly remove the 30-phosphate on PIP3 and terminate PI3K signaling. Many human tumors are associated with loss of phosphatase and tensin homolog function, as well as elevated levels of PIP3, which are now two of the most frequently altered gene functions in human cancers (Lawrence et al., 2014; Fruman et al., 2017).

\section{Protein Kinase B}

Members of the protein kinase B (AKT)-serine/threonine kinase family exist in three main isoforms (Akt1, Akt2, and Akt3) and are common downstream effectors of PI3K signaling pathway (Fresno Vara et al., 2004). AKT is a master regulator of tumor cell invasion, migration, and metastasis capable of phosphorylating a number of regulatory proteins such as ArfGAP with coiled coil, POSH, P21/Cdc42/Rac1-activated kinase 1, Girdin, and so forth (Manning and Cantley, 2007; Jiang and 
Liu, 2009; Dillon and Muller, 2010; Xue et al., 2012; Li et al., 2015). As a proto-oncoprotein, AKT can inhibit apoptosis by binding to Bcl-2-associated $\mathrm{X}$ protein and hinder its ability to form openings in the mitochondrial outer membrane. Evidence reveals that in prostate cancer cells, activation of AKT corresponds to increased resistance to apoptosis (Patrucco et al., 2004; Guimaraes et al., 2015). Upon PIP3 formation, AKT and its upstream activating kinase, phosphoinositide-dependent kinase1 , will translocate from the cytoplasm to the plasma membrane. The constitutively active phosphoinositide-dependent kinase-1 will then induce the phosphorylation of AKT kinase domain at Thr308 and Ser473 in the carboxyl-terminal position to initiate the complete activation of AKT (Carpenter and Jiang, 2013). AKT is capable of phosphorylating various substrates associated with cell metabolism, proliferation, survival, and motility (Liu et al., 2014). For example, AKT activity can positively regulate cell survival through activation of IkB kinase, a regulator of nuclear factor $\kappa$ light-chain enhancer of activated B cells (Guimaraes et al., 2015). Mutations in its pH domain have been frequently found in cancers, which further supports the notion that AKT is an important effector for PI3K-associated oncogenic signaling (Fruman et al., 2017; Manning and Toker, 2017). AKT activation is also reversible as protein phosphatase $2 \mathrm{~A}$ (PP2A) and pleckstrin homology domain leucine-rich repeat protein phosphatase are capable of dephosphorylating pAKT and convert it back to inactive AKT (Wang, 2013; Li and Wang, 2014).

\section{Mechanistic Target of Rapamycin}

As an essential protein highly conserved through evolution, the mechanistic target of rapamycin (mTOR) is known to regulate downstream signaling cascades by integrating both intracellular and extracellular signals (Meng et al., 2018). Functions of mTOR are carried out by two cellular complexes, mTORC1 and mTORC2, each with its own distinct subunit composition and substrate selectivity (Saxton and Sabatini, 2017). mTORC1 consists of five components: mTOR, Raptor, mLST8, PRAS40, and DEPTOR (Hara et al., 2002; Kim et al., 2002, 2003; Sancak et al., 2007; Vander Haar et al., 2007; Wang et al., 2007; Peterson et al., 2009; Meng et al., 2018). mTORC2 is composed of six components; mTOR, Rctor, mLST8,DEPTOR, mSin1, and Proctor 1/2 (Gaullier et al., 1998; Kim et al., 2003; Jacinto et al., 2004, 2006; Sarbassov et al., 2004; Yang et al., 2006; Pearce et al., 2007; Schroder et al., 2007; Peterson et al., 2009; Dou et al., 2013; Guimaraes et al., 2015; Meng et al., 2018). As a key signaling node, mTORC1 regulates important cellular processes, including autophagy, protein and lipid synthesis, and growth factor signaling (Jewell and Guan, 2013; Saxton and Sabatini, 2017; Meng et al., 2018). mTORC1 is able to stimulate protein synthesis and cell proliferation through the phosphorylation of S6 kinase-1 (S6K1) and 4EBP1, which elevates glycolysis and protein biosynthesis to initiate a "carcinogenic" metabolic reprogramming and regulates translation initiation, respectively (Ma and Blenis, 2009; Magnuson et al., 2012; Dibble and Cantley, 2015; Fruman et al., 2017). On the other hand, mTORC2 is primarily responsible for cell survival, growth, proliferation, and cytoskeletal remodeling through phosphorylation of protein kinases $\mathrm{A}, \mathrm{G}$, and $\mathrm{C}$ family members (Sarbassov et al., 2004; Gan et al., 2012; Thomanetz et al.,
2013; Li and Gao, 2014; Ebner et al., 2017). The PI3K/AKT signaling pathway is known to stimulate mTORC activity by inactivating tuberous sclerosis complex (TSC) 1/2 phosphorylation (Manning et al., 2002; Carpenter and Jiang, 2013; Rad et al., 2018). TSC consists of three components: TSC1, TSC2, and TBC1D7. The TSC complex primarily functions to inhibit the mTORC1 activator Ras homolog enriched in the brain (Inoki et al., 2002; Manning et al., 2002).

Current studies suggest that mTOR is involved in a broad spectrum of functions, including lipid generation, biosynthesis of nucleotide precursors, metabolic transformation, metastasis, and so forth (Yecies et al., 2011; Ben-Sahra et al., 2013; Valvezan et al., 2017; Rad et al., 2018). Activated mTOR will also enhance the production of de novo proteins, mainly through an increased number of ribosomes and accelerated protein translation (Iadevaia et al., 2014). In addition, mTOR can speed up G1 to $\mathrm{S}$ transition, which will drive more rapid cell proliferation and growth (Fingar et al., 2004). Examples of proteins regulated by mTOR include cyclin D1, hypoxiainducible factor 1 (HIF), and vascular endothelial growth factor, which are required for the survival of many tumors (Mu et al., 1995; Stenmark et al., 1996; Guimaraes et al., 2015). $\mathrm{mTOR} /$ ribosomal protein S6 kinase $\beta-1$ (p70S6K1) can also upregulate AP-1 as well as other proangiogenic factors in promoting carcinogenic effects. Given the various cancerous characteristics promoted by mTOR activation, it is not surprising to find mTOR activation in approximately $70 \%$ of human cancers, and this activation is often correlated with resistance to cancer therapy and overall poor survival rate for the patient (Jiang and Liu, 2008; Forbes et al., 2011; Rad et al., 2018).

\section{Arsenic and the PI3K/AKT/mTOR Pathway}

The PI3K/AKT/mTOR pathway has been regarded as a key regulator for many physiologic processes, including cell proliferation, growth, metabolism, and macromolecular synthesis (Li and Wang, 2014; Guimaraes et al., 2015). Although PI3K/AKT and mTOR are two separate pathways, they are often considered a single unique pathway owing to functional interconnectedness. PI3K is evolutionarily conserved to respond to external growth signals. In mammals, activation of the pathway begins as a cellular response to various extracellular stimuli, including epidermal growth factor receptor (EGFR), PDGF receptor, insulin-like growth factor receptor, and insulin receptor (Li and Wang, 2014; Fruman et al., 2017). In consideration of its many important physiologic roles, a homeostatically balanced PI3K/AKT/mTOR network is fundamental in maintaining normal cellular growth. On the other hand, aberrant activation of the signaling cascade will lead to considerable interruptions in cell proliferation, which can result in angiogenesis, metastatic competence, and potential therapy resistance (Porta et al., 2014). In other words, the PI3K/AKT/mTOR pathway exists as one of the most attractive targets for cancer development. Evidence suggests that chronic arsenic exposure-induced cell proliferation, migration, invasion, and anchorage-independent growth are strongly correlated with PI3K and AKT activation (Carpenter and Jiang, 2013). A likely mechanism of arsenic-induced pathway activation is through stimulating upstream signals such as EGFR, which has been shown to induce aberrant epithelial cell proliferation (Simeonova et al., 2002; Gao et al., 2004; 
Hennessy et al., 2005; Jiang and Liu, 2008, 2009; Andrew et al., 2009; Lee et al., 2010; Wen et al., 2010; Carpenter and Jiang, 2013). EGFR is a member of the ErbB family of receptor tyrosine kinases and is commonly overexpressed in human malignancies such as cancers of the lung, breast, esophageal, and others (Hirsch et al., 2003; Suzuki et al., 2005; Seshacharyulu et al., 2012; Carpenter and Jiang, 2013). Conformational changes resulting from ligand bindinginduced EGFR dimerization allow for autophosphorylation at the C-terminal section of the receptor. Activated EGFR can interact with the p85 regulatory subunit of PI3K, which will stimulate the catalytic activity of p110 and initiate the activation of the PI3K/AKT pathway (Carpenter and Jiang, 2013). Subsequently, AKT can indirectly inhibit TSC2, thereby activating mTOR signaling (Carnero, 2010; Jiang and Carpenter, 2013). In fact, studies have shown that cells treated with arsenic along with PI3K inhibitor LY294002 will result in reduced p70S6K phosphorylation and subsequent mTOR activation, indicating that mTOR activity is regulated by upstream PI3K activation (Wang and Proud, 1997; Jung et al., 2003; Skinner et al., 2004; Yoon et al., 2006; Altman et al., 2008; Castorina et al., 2008; Lee et al., 2010; Carpenter et al., 2011; Wu et al., 2011; Carpenter and Jiang, 2013). EGFR, activated PI3K/AKT, and mTOR pathways have all been shown to stimulate cell transformation and angiogenesis (see Fig. 1). Effectors of the signaling cascade include HIF-1, AP-1, Forkhead box $\mathrm{O}$, and NF-kB, important factors in promoting cancer formation (Hu et al., 2005; Xia et al., 2006; Fang et al., 2007; Jiang and Liu, 2009; Carpenter and Jiang, 2013).

\section{Arsenic Can Differentially Regulate PI3K/AKT/mTOR in Different Cell Types}

Cancer Promoting. As a potent human carcinogen, chronic arsenic exposure has long been known to induce cancers of the lungs. In multiple studies, human bronchial epithelial cells illustrated activated AKT and mTOR activity after arsenic exposure (Zhang et al., 2006; Beezhold et al., 2011; Carpenter et al., 2011; Liu et al., 2011). Despite high variability in dosage $(0-20 \mu \mathrm{M})$, type of compound $\left(\mathrm{NaAsO}_{2}\right.$, $\mathrm{AsCl}_{3}$ ), and length of exposure (4 hours to 26 weeks), all the treatment conditions resulted in increased pathway activity compared with the control groups (Table 1). Along with activated AKT and mTOR activity, arsenic-exposed cells also demonstrated a higher rate of proliferation, survival, and anchorage-independent growth, all of which are unique hallmarks of malignant cell transformation. Similar results were also found in primary human bronchial epithelial cells (Wang et al., 2012). In addition to bronchial epithelial cells, mouse epidermis-derived mouse epidermis-derived cells JB6Cl41, as well as normal human bladder SV-HUC-1 and A375 cells, all demonstrated activated PI3K and AKT activity after arsenic exposure (Ouyang et al., 2006; Wang, 2013; Li et al., 2015). In vivo experiments treating Wistar rats and $\mathrm{C} 57 \mathrm{BL} / 6$ mice with $1.0 \mu \mathrm{mol} / \mathrm{liter}$ of roxarsone revealed activated $\mathrm{PI} 3 \mathrm{~K}$ and AKT phosphorylation in the vascular endothelial cells (Wang et al., 2016). In fact, both acute and chronic arsenic treatments promoted PI3K/AKT phosphorylation. In one study, after treating SV-HUC-1 cells with $1 \mu \mathrm{M}$ arsenic trioxide for 8-10 months, results from Western blotting analysis showed significant elevation in the

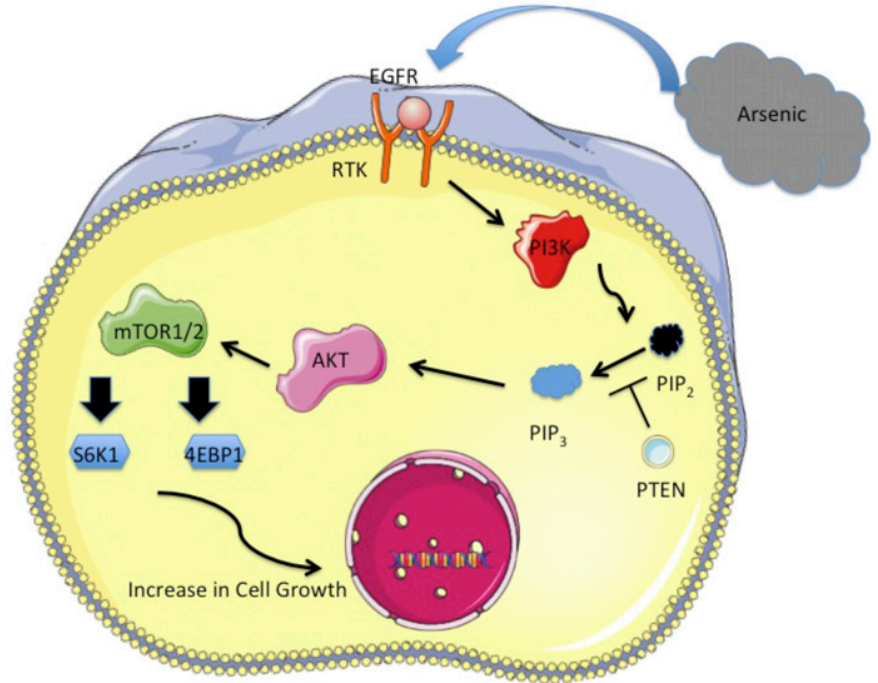

Fig. 1. Graphical representation illustrating the role of the PI3K/AKT/ mTOR pathway in promoting cellular growth.

expression of mTOR protein, as well as phosphorylation of PI3K and AKT (Michailidi et al., 2015).

Cancer Suppressing. Whereas evidence suggests that arsenic can activate the PI3K/AKT/mTOR pathway and stimulating cell proliferation in normal, cells such as BEAS2B and SV-HUC-1, the opposite phenomenon seems to occur in cancerous cells. Specifically, arsenic induces apoptosis to varying degrees in different types of cancer cells, such as human colorectal adenocarcinoma cell (HT-29) colon, neuroblastoma, prostate, B-cell leukemia, and gastrointestinal cancer cells (Akao et al., 1999; Cha et al., 2006; Ma et al., 2014; You et al., 2015; Stevens et al., 2017). In most of these studies, arsenic trioxide is used instead of sodium arsenite or arsenic trichloride, which are typically used for treatment of noncarcinoma cell studies (see Tables 1 and 2). Arsenic trioxide has been used as a key ingredient in traditional Chinese medicine for more than 5000 years (Au, 2011). Over time, the demand and appeal for arsenic diminished owing to its intrinsic toxicity. Nevertheless, in the 1970 s, researchers from China discovered the therapeutic effects of arsenic trioxide against acute promyelocytic leukemia (APL), and the Food and Drug Administration later approved its use in 2000 (Antman, 2001). Today, arsenic trioxide is still being used as an effective drug against APL, mainly through inducing cancer cell death (Baysan et al., 2007; Li and Wang, 2014); however, tolerable doses of arsenic trioxide have been most effective in inducing apoptosis in acute APL, but not as effective in other malignant cells (Mann et al., 2008). Furthermore, arsenic may preferentially target cancer cells rather than normal cells. For instance, arsenic trioxide (ATO) limits PI3K/AKT-induced cellular proliferation and increases the amount of apoptosis in B-cell chronic lymphocytic leukemia cells, but not in normal peripheral blood lymphocytes (Redondo-Muñoz et al., 2010).

In both human Burkitt lymphoma and human leukemia cell lines, high exposure to ATO (i.e., $>5 \mu \mathrm{M}$ for $\geq 24$ hours) induce cell apoptosis (Chen et al., 1996; Li and Broome, 1999; Choi et al., 2002; Baysan et al., 2007; Li and Wang, 2014). A likely explanation for this phenomenon is the induction of ROS through arsenic toxicity, which in turn decreases AKT activity 
TABLE 1

Studies showing arsenic activating PI3K/AKT/mTOR pathway

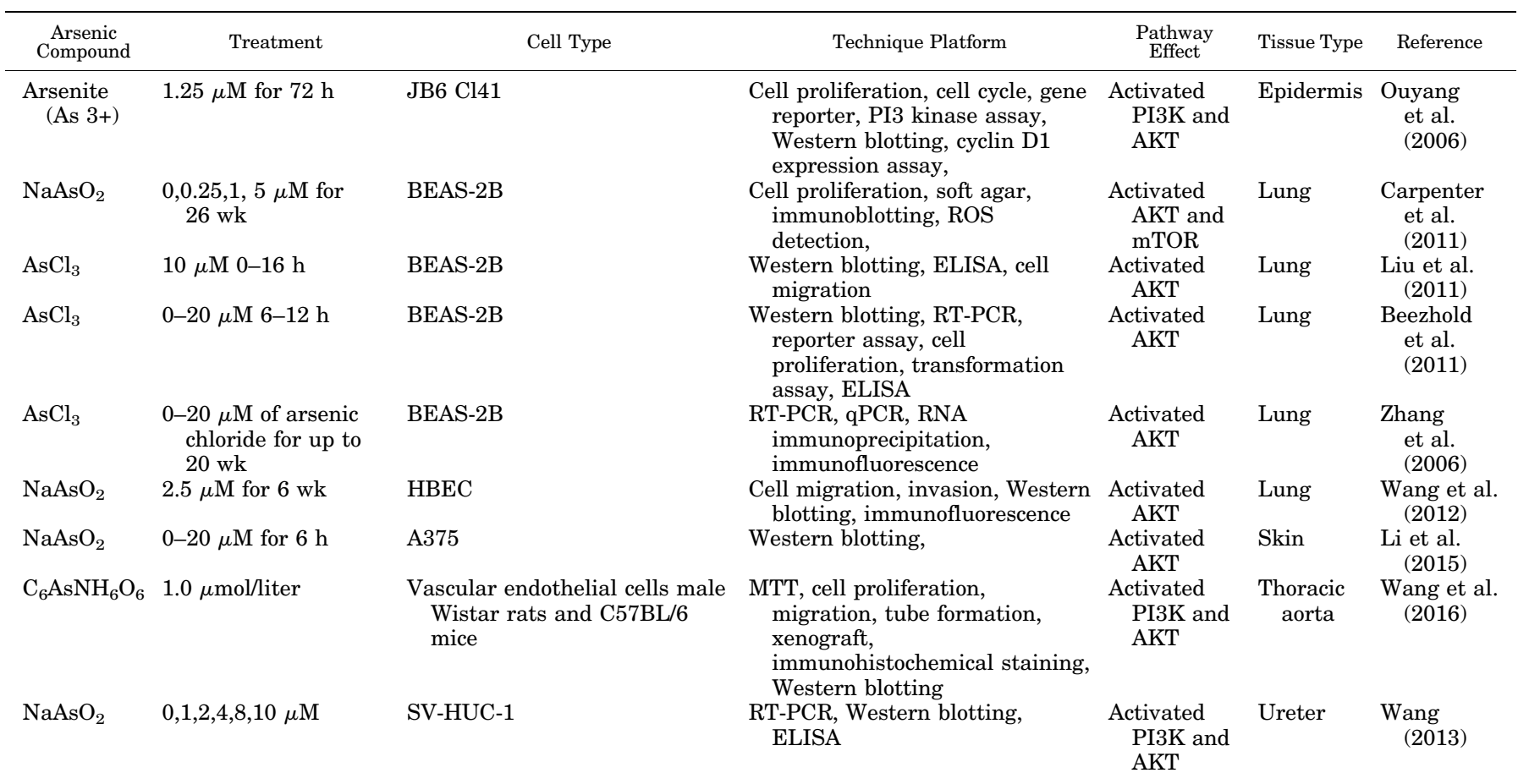

BEAS-2B, human bronchial epithelial cells; CLL, chronic lymphocytic leukemia; ELISA, enzyme-linked immunosorbent assay; GSH, glutathione; HBEC, human bronchial epithelial cells; qRT-PCR, quantitative reverse transcription-polymerase chain reaction.

and promotes proapoptotic features. In human gastric cancer (SGC-7901) cell lines, ATO for up to 72 hours led to decreased phosphorylation at two AKT sites, Ser 473 and Thr308, although the protein levels stayed relatively same, indicating that arsenic can reduce activation of AKT rather than the total protein (Gao et al., 2014). In another study led by Wang et al. (2017), arsenic disulfide has been found to inhibit the AKT/mTOR signaling pathway and induce autophagy and apoptosis in several osteosarcoma cell lines. Specifically, human osteosarcoma 143B, human osteosarcoma cell MG-63, U-2OS, and human osteosarcoma cells were subjected to either 24 or 48 hours of treatment. Doses of arsenic ranged from 3.02 to $13.06 \mu \mathrm{M}$. Western blotting data suggest that arsenic disulfide led to a reduction in both the protein amount as well as activity/phosphorylation of mTOR and AKT (Wang et al., 2017). In a separate study based on chondrosarcoma cells, researchers were able to find similar therapeutic benefits of arsenic in suppressing cancer cell growth (Jiao et al., 2015). Human chondrosarcoma cells HCS-2/8, human chondrosarcoma cell OUMS-27, and SW1353 were subject to 12,24 , or 48 hours of ATO exposure, concentrations ranging from 1 to $20 \mu \mathrm{M}$. MTT assays after treatment illustrated decreased cell viability and high levels of apoptosis. Western blot analyses demonstrated a dosedependent decrease in AKT and mTOR phosphorylation arsenic exposure, which led the researchers to conclude that ATO may induce apoptosis via inhibition of the AKT/mTOR pathway.

On the other hand, ATO may not always be effective when acting alone. In one study, HL60 cells were treated with both ATO and 2-deoxy-D-glucose, an antiglycolytic drug, resulting in dephosphorylated AKT; however, ATO alone led to insignificant changes to the phosphorylation levels (Estañ et al., 2012). Similarly, lonidamine, an antitumor drug, has also been shown to inactivate PI3K/AKT when used in combination with ATO (Calviño et al., 2011). In addition, the dosage and length of ATO exposure also seem to control the PI3K/AKT pathway. In a study using both NB4 and gastric cancer cells, after the initial 4-hour ATO treatment, AKT phosphorylation heightened but decreased again after 16-24 hours of treatment ( $\mathrm{Li}$ et al., 2009). The controversial biologic effect of arsenic, and hence its biphasic effect on carcinogenesis, may depend on the type of compound and strength of exposure (Wang et al., 2016).

Challenges in Targeting PI3K/AKT/mTOR Pathway for Cancer Therapy. Considering the many important roles in multiple physiologic functions, cell growth, and metabolism, the PI3K/AKT and mTOR pathways are crucial targets for cancer therapy; however, efforts using target inhibitors have proven inefficient mainly for three reasons. First, activation of the pathways can be initiated by various receptors owing to cancer cells' high plasticity in amplifying the upstream targets to stimulate compensatory pathways and maintaining persistent signal flow (Fruman et al., 2017). Second, persistent administration of the inhibitors can induce resistance owing to mutations of regulatory genes responsible for the pathways. In fact, the PI3K and mTOR pathways are important targets for resistance to cancer immunotherapy (Fruman et al., 2017). Third, studies suggest that significant reductions in PI3K and AKT phosphorylation are needed to generate optimal therapeutic outcome in most cancer patients (Fruman et al., 2017). For instance, to induce hyperglycemic response in mice, inhibition of hepatic PI3K/AKT signaling needs to reach more than $90 \%$ efficiency (Taniguchi et al., 2006; Fruman et al., 2017); however, inhibitors with the greatest potentials for effective therapeutic activity, such as 
TABLE 2

Studies showing arsenic inhibiting PI3K/AKT/mTOR pathway

\begin{tabular}{|c|c|c|c|c|c|c|}
\hline $\begin{array}{l}\text { Arsenic } \\
\text { Compound }\end{array}$ & Treatment & Cell Type & Technique Platform & Pathway Effect & Tissue Type & Reference \\
\hline $\mathrm{NaAsO}_{2}$ & $0-2 \mu \mathrm{M}$ for 7 days & 3T3-L1 & $\begin{array}{l}\text { qRT-PCR, Western blotting, } \\
\text { immunofluorescence, }\end{array}$ & Inactivation of $\mathrm{AKT}$ & Adipocytes & $\begin{array}{l}\text { Xue et al. } \\
\quad(2011)\end{array}$ \\
\hline $\mathrm{As}_{2} \mathrm{O}_{3}$ & $\begin{array}{l}0-10 \mu \mathrm{M} \text { for } 48 \mathrm{~h} \text { or } 5 \mu \mathrm{M} \\
\quad \text { for up to } 72 \mathrm{~h}\end{array}$ & SW1353 & $\begin{array}{l}\text { MTT, Western blotting, cell } \\
\text { viability, clone formation, } \\
\text { apoptosis, } \\
\text { immunofluorescence, }\end{array}$ & $\begin{array}{l}\text { Inactivation of AKT and } \\
\text { mTOR }\end{array}$ & Chondrosarcoma & $\begin{array}{l}\text { Jiao et al. } \\
\quad(2015)\end{array}$ \\
\hline $\mathrm{As}_{4} \mathrm{O}_{6}$ & $1 \mu \mathrm{M}$ for $48 \mathrm{~h}$ & SW620 & $\begin{array}{l}\text { Cell viability, ROS } \\
\text { generation, cell cycle, } \\
\text { nuclear staining, Western } \\
\text { blotting, inhibitors assay }\end{array}$ & Decreased PI3K/AKT & $\begin{array}{l}\text { Colorectal } \\
\text { cancer }\end{array}$ & $\begin{array}{l}\text { Nagappan } \\
\text { et al. } \\
\text { (2017) }\end{array}$ \\
\hline $\mathrm{As}_{2} \mathrm{O}_{3}$ & $0-16 \mu \mathrm{M}$ for $24 \mathrm{~h}$ & SGC-7901 & $\begin{array}{l}\text { Cell viability, mitochondrial } \\
\text { membrane potential, } \\
\text { apoptosis, Western } \\
\text { blotting }\end{array}$ & Inactivation of $\mathrm{AKT}$ & Gastric cancer & $\begin{array}{l}\text { Gao et al. } \\
\quad(2014)\end{array}$ \\
\hline $\mathrm{As}_{2} \mathrm{O}_{3}$ & $3 \mathrm{mg} / \mathrm{kg}$ for 7 days & $\begin{array}{l}\text { Male Wistar } \\
\text { rats }\end{array}$ & $\begin{array}{l}\text { Histologic analysis, Western } \\
\text { blotting }\end{array}$ & $\begin{array}{l}\text { Inactivation of PI3K and } \\
\text { AKT }\end{array}$ & Liver & $\begin{array}{l}\text { Zhang et al. } \\
\quad(2017)\end{array}$ \\
\hline NA & NA & U937 & NA & Inactivation of AKT & Myeloid cancer & $\begin{array}{l}\text { Choi et al. } \\
\text { (2002) }\end{array}$ \\
\hline $\mathrm{As}_{2} \mathrm{O}_{3}$ & $\begin{array}{l}1 \mu \mathrm{M} \text { for NB4 and } 4 \mu \mathrm{M} \text { for } \\
\text { THP1 cells for } 4 \mathrm{~h}\end{array}$ & $\begin{array}{l}\text { NNA, B4, } \\
\text { THP1 }\end{array}$ & $\begin{array}{l}\text { Flow cytometry, cell } \\
\text { proliferation, viability, } \\
\text { apoptosis, necrosis, ROS } \\
\text { and GSH level, } \\
\text { immunoblotting }\end{array}$ & $\begin{array}{l}\text { ATO alone has no effect on } \\
\text { AKT, only with 2-DG (2- } \\
\text { deoxy-D-glucose) }\end{array}$ & Myeloid cancer & $\begin{array}{l}\text { Estañ et al. } \\
\quad(2012)\end{array}$ \\
\hline $\mathrm{As}_{2} \mathrm{O}_{3}$ & $\begin{array}{l}1 \mu \mathrm{M} \text { for } 24 \mathrm{~h} \text { in } \mathrm{NB} 4 \text { cells } \\
\text { and } 10 \mu \mathrm{M} \text { for } 16 \mathrm{~h} \text { in } \\
\mathrm{MGC} 803 \text { cells }\end{array}$ & $\begin{array}{l}\text { NB4 and } \\
\text { MGC803 }\end{array}$ & $\begin{array}{l}\text { Cell viability, cell cycle, } \\
\text { Western blotting }\end{array}$ & $\begin{array}{l}\text { Inactivation of PI3K and } \\
\text { AKT }\end{array}$ & $\begin{array}{l}\text { Gastric and } \\
\text { myeloid } \\
\text { cancer }\end{array}$ & $\begin{array}{l}\text { Li et al. } \\
\quad(2009)\end{array}$ \\
\hline $\mathrm{As}_{2} \mathrm{~S}_{2}$ & $\begin{array}{l}3.02-13.06 \mu \mathrm{M} \text { for } 24 \text { or } \\
48 \mathrm{~h} \text { treatment }\end{array}$ & $\begin{array}{l}\text { 143B, } \\
\text { MG-63, } \\
\text { U-2OS, } \\
\text { and HOS }\end{array}$ & $\begin{array}{l}\text { Cell viability, clone } \\
\text { formation, cell cycle, } \\
\text { apoptosis, histopathology, } \\
\text { immunohistochemistry, } \\
\text { human osteosarcoma } \\
\text { xenograft, Western } \\
\text { blotting, ROS generation }\end{array}$ & $\begin{array}{l}\text { Inactivation of AKT and } \\
\text { mTOR }\end{array}$ & Osteosarcoma & $\begin{array}{l}\text { Wang et al. } \\
\quad(2017)\end{array}$ \\
\hline $\mathrm{As}_{2} \mathrm{O}_{3}$ & $3 \mu \mathrm{M}$ for $48 \mathrm{~h}$ & B-CLL & $\begin{array}{l}\text { Cell apoptosis, ROS, } \\
\text { Western blotting }\end{array}$ & $\begin{array}{l}\text { Inactivation of PI3K and } \\
\text { AKT }\end{array}$ & Peripheral blood & $\begin{array}{l}\text { Redondo- } \\
\text { Muñoz } \\
\text { et al. } \\
\text { (2010) }\end{array}$ \\
\hline
\end{tabular}

ATO, arsenic trioxide; B-CLL, B-cell chronic lymphocytic leukemia; GSH, glutathione; NA, not applicable; qRT-PCR, quantitative reverse transcription-polymerase chain reaction.

pan-pI3K and pan-specific PI3K/mTOR inhibitors, also exert high toxicity burdens; so although high doses may be effective in targeting tumor tissues, the resulting adverse effects, such as hyperglycemia and liver damage-releasing transaminases, are limiting factors for administrating most effective dosages.

\section{Discussion}

More than 200 million people around the world are exposed to arsenic at levels greater than the maximum contaminant level of $10 \mathrm{ppb}$, through drinking water, inhalation, or diet. As a class 1 human carcinogen, exposure to arsenic has been documented to cause neurodevelopmental deficits, cardiovascular disease, and various human cancers, including the lung, bladder, kidney, liver, and others. Various mechanisms of arsenic-induced carcinogenesis have been proposed, and this review focuses specifically on the PI3K/AKT/mTOR pathway to understand more fully the arsenic's ability to induce the intrinsic characteristics of cancer development (cell proliferation and antiapoptosis) as a critical pathway for a multitude of biologic and physiologic functions, such as cell survival, proliferation, apoptosis, and metabolism. Multiple studies have demonstrated a link between arsenic and the activity of the PI3K/AKT/mTOR pathway in stimulating malignant cell transformation through uncontrolled cell proliferation. In addition, it is interesting to note that mTOR acts as a major negative regulator of autophagy, a process in which old and damaged cells are degraded (Heras-Sandoval et al., 2014). The activation of the PI3K/AKT/mTOR signaling pathway not only stimulates growth but can also halt autophagy, which may promote the extended survival of damaged cells and subsequent replication. In fact, previous studies have illustrated that arsenic can induce prolonged activation of Nrf2 through autophagic dysfunction as a way of promoting cancer development (Lau et al., 2013). The link between arsenic and the PI3K/AKT/mTOR pathway-induced autophagy may be an interesting area for future studies. On the other hand, ATO has been used successfully to treat APL through inducing cell death in the cancer cells. The specificity of this successful treatment is likely due to the narrow mutations of specific proapoptotic proteins that drive promyelocytic leukemia protein. Current studies suggest that arsenic can manipulate the PI3K/AKT/mTOR pathway to induce cell proliferation as well as apoptosis, two conflicting mechanisms. The ability for arsenic to achieve opposite cellular responses may be related to the exposure conditions (dose and time) as well as the type of cells used. It is imperative for future studies to establish and pinpoint the exact conditions for arsenic to differentially regulate the PI3K/AKT/mTOR pathway to maximize the therapeutic and minimize the carcinogenic effects of arsenic. 


\section{Authorship Contributions:}

Participated in research design: Chen.

Wrote or contributed to the writing of the manuscript: Chen, Costa.

\section{References}

Akao Y, Nakagawa Y, and Akiyama K (1999) Arsenic trioxide induces apoptosis in neuroblastoma cell lines through the activation of caspase 3 in vitro. FEBS Lett 455:59-62.

Altman JK, Yoon P, Katsoulidis E, Kroczynska B, Sassano A, Redig AJ, Glaser H, Jordan A, Tallman MS, Hay N, et al. (2008) Regulatory effects of mammalian target of rapamycin-mediated signals in the generation of arsenic trioxide responses. J Biol Chem 283:1992-2001.

Andrew AS, Mason RA, Memoli V, and Duell EJ (2009) Arsenic activates EGFR pathway signaling in the lung. Toxicol Sci 109:350-357.

Antman KH (2001) Introduction: the history of arsenic trioxide in cancer therapy. Oncologist 6 (Suppl 2):1-2.

$\mathrm{Au}$ WY (2011) A biography of arsenic and medicine in Hong Kong and China. Hong Kong Med J 17:507-513.

Axelson O, Dahlgren E, Jansson CD, and Rehnlund SO (1978) Arsenic exposure and mortality: a case-referent study from a Swedish copper smelter. Br J Ind Med 35:8-15. Barchowsky A, Dudek EJ, Treadwell MD, and Wetterhahn KE (1996) Arsenic induces oxidant stress and NF-kappa B activation in cultured aortic endothelial cells. Free Radic Biol Med 21:783-790.

Bartholomeusz C and Gonzalez-Angulo AM (2012) Targeting the PI3K signaling pathway in cancer therapy. Expert Opin Ther Targets 16:121-130.

Baysan A, Yel L, Gollapudi S, Su H, and Gupta S (2007) Arsenic trioxide induces apoptosis via the mitochondrial pathway by upregulating the expression of Bax and Bim in human B cells. Int J Oncol 30:313-318.

Beezhold K, Liu J, Kan H, Meighan T, Castranova V, Shi X, and Chen F (2011) miR190-mediated downregulation of PHLPP contributes to arsenic-induced Akt activation and carcinogenesis. Toxicol Sci 123:411-420.

Ben-Sahra I, Howell JJ, Asara JM, and Manning BD (2013) Stimulation of de novo pyrimidine synthesis by growth signaling through mTOR and S6K1. Science 339 $1323-1328$

Calviño E, Estañ MC, Simón GP, Sancho P, Boyano-Adánez MdelC, de Blas E Bréard J, and Aller P (2011) Increased apoptotic efficacy of lonidamine plus arsenic trioxide combination in human leukemia cells: reactive oxygen species generation and defensive protein kinase (MEK/ERK, Akt/mTOR) modulation. Biochem Pharmacol 82:1619-1629.

Carnero A (2010) The PKB/AKT pathway in cancer. Curr Pharm Des 16:34-44.

Carpenter RL and Jiang BH (2013) Roles of EGFR, PI3K, AKT, and mTOR in heavy metal-induced cancer. Curr Cancer Drug Targets 13:252-266.

Carpenter RL, Jiang Y, Jing Y, He J, Rojanasakul Y, Liu LZ, and Jiang BH (2011) Arsenite induces cell transformation by reactive oxygen species, AKT, ERK1/2, and p70S6K1. Biochem Biophys Res Commun 414:533-538.

Castorina A, Tiralongo A, Cavallo D, Loreto C, Carnazza ML, Iavicoli S, and D'Agata V (2008) Expression profile of ErbB receptor's family in human alveolar type 2-like cell line A549 exposed to hexavalent chromium. Toxicol In Vitro 22:541-547.

Cha Y, Park D-W, Lee CH, Baek SH, Kim SY, Kim JR, and Kim JH (2006) Arsenic trioxide induces apoptosis in human colorectal adenocarcinoma HT-29 cells through ROS. Cancer Res Treat 38:54-60.

Chen GQ, Zhu J, Shi XG, Ni JH, Zhong HJ, Si GY, Jin XL, Tang W, Li XS, Xong SM, et al. (1996) In vitro studies on cellular and molecular mechanisms of arsenic trioxide (As2O3) in the treatment of acute promyelocytic leukemia: As2O3 induces NB4 cell apoptosis with downregulation of Bcl-2 expression and modulation of PML-RAR alpha/PML proteins. Blood 88:1052-1061.

Chen Q and Costa M (2017) Epigenetic phenomena of arsenic and histone tai modifications: implications for diet and nutrition, in Handbook of Nutrition, Diet, and Epigenetics, Springer, Cham, Switzerland.

Chen Y, Graziano JH, Parvez F, Liu M, Slavkovich V, Kalra T, Argos M, Islam T, Ahmed A, Rakibuz-Zaman M, Hasan R, Sarwar G, Levy D, van Geen A, and Ahsan $\mathrm{H}$ (2011) Arsenic exposure from drinking water and mortality from cardiovascular disease in Bangladesh: prospective cohort study. BMJ 342:2431.

Choi YJ, Park JW, Suh SI, Mun KC, Bae JH, Song DK, Kim SP, and Kwon TK (2002) Arsenic trioxide-induced apoptosis in U937 cells involve generation of reactive oxygen species and inhibition of Akt. Int J Oncol 21:603-610.

Czech MP (2000) PIP2 and PIP3: complex roles at the cell surface. Cell 100:603-606.

Dibble CC and Cantley LC (2015) Regulation of mTORC1 by PI3K signaling. Trends Cell Biol 25:545-555.

Dillon RL and Muller WJ (2010) Distinct biological roles for the akt family in mammary tumor progression. Cancer Res 70:4260-4264.

Dou Z, Pan JA, Dbouk HA, Ballou LM, DeLeon JL, Fan Y, Chen JS, Liang Z, Li G, Backer JM, et al. (2013) Class IA PI3K p110ß subunit promotes autophagy through Rab5 small GTPase in response to growth factor limitation. Mol Cell 50:29-42.

Ebner M, Sinkovics B, Szczygieł M, Ribeiro DW, and Yudushkin I (2017) Localization of mTORC2 activity inside cells. J Cell Biol 216:343-353.

Enterline PE, Henderson VL, and Marsh GM (1987) Exposure to arsenic and respiratory cancer: a reanalysis. Am J Epidemiol 125:929-938.

Estañ MC, Calviño E, de Blas E, Boyano-Adánez MdelC, Mena ML, Gómez-Gómez M, Rial E, and Aller P (2012) 2-Deoxy-D-glucose cooperates with arsenic trioxide to induce apoptosis in leukemia cells: involvement of IGF-1R-regulated Akt/mTOR, MEK/ERK and LKB-1/AMPK signaling pathways. Biochem Pharmacol 84 1604-1616

Fang J, Ding M, Yang L, Liu LZ, and Jiang BH (2007) PI3K/PTEN/AKT signaling regulates prostate tumor angiogenesis. Cell Signal 19:2487-2497.

Fingar DC, Richardson CJ, Tee AR, Cheatham L, Tsou C, and Blenis J (2004) mTOR controls cell cycle progression through its cell growth effectors S6K1 and 4E-BP1/ eukaryotic translation initiation factor 4E. Mol Cell Biol 24:200-216.
Forbes SA, Bindal N, Bamford S, Cole C, Kok CY, Beare D, Jia M, Shepherd R, Leung $\mathrm{K}$, Menzies A et al (2011) COSMIC: mining complete cancer genomes in the Catalogue of Somatic Mutations in Cancer. Nucleic Acids Res 39:D945-D950.

Fresno Vara JA, Casado E, de Castro J, Cejas P, Belda-Iniesta C, and GonzálezBarón M (2004) PI3K/Akt signalling pathway and cancer. Cancer Treat Rev 30: 193-204

Fruman DA, Chiu H, Hopkins BD, Bagrodia S, Cantley LC, and Abraham RT (2017) The PI3K pathway in human disease. Cell 170:605-635.

Gan X, Wang J, Wang C, Sommer E, Kozasa T, Srinivasula S, Alessi D, Offermanns S, Simon MI, and Wu D (2012) PRR5L degradation promotes mTORC2-mediated PKC- $\delta$ phosphorylation and cell migration downstream of $\mathrm{G} \alpha 12$. Nat Cell Biol 14: $686-696$.

Gao N, Ding M, Zheng JZ, Zhang Z, Leonard SS, Liu KJ, Shi X, and Jiang BH (2002) Vanadate-induced expression of hypoxia-inducible factor $1 \alpha$ and vascular endothelial growth factor through phosphatidylinositol 3-kinase/Akt pathway and reactive oxygen species. J Biol Chem 277:31963-31971.

Gao N, Shen L, Zhang Z, Leonard SS, He H, Zhang XG, Shi X, and Jiang BH (2004) Arsenite induces HIF- $1 \alpha$ and VEGF through PI3K, Akt and reactive oxygen species in DU145 human prostate carcinoma cells. Mol Cell Biochem 255:33-45.

Gao YH, Zhang HP, Yang SM, Yang Y, Ma YY, Zhang XY, and Yang YM (2014) Inactivation of Akt by arsenic trioxide induces cell death via mitochondrialmediated apoptotic signaling in SGC-7901 human gastric cancer cells. Oncol Rep 31:1645-1652.

Gaullier JM, Simonsen A, D'Arrigo A, Bremnes B, Stenmark H, and Aasland R (1998) FYVE fingers bind PtdIns(3)P. Nature 394:432-433.

Guimaraes I, Tessarollo N, Lyra-Junior P, Santos D, Zampier R, de Oliveira L, Sigueira K, Silva I, and Rangel L (2015) Targeting the PI3K/AKT/mTOR pathway in cancer cells, in Updates on Cancer Treatment (Silva I and Rangel L eds) InTechOpen, London.

Hara K, Maruki Y, Long X, Yoshino K, Oshiro N, Hidayat S, Tokunaga C, Avruch J, and Yonezawa K (2002) Raptor, a binding partner of target of rapamycin (TOR), mediates TOR action. Cell 110:177-189.

Hennessy BT, Smith DL, Ram PT, Lu Y, and Mills GB (2005) Exploiting the PI3K/ AKT pathway for cancer drug discovery. Nat Rev Drug Discov 4:988-1004.

Heras-Sandoval D, Pérez-Rojas JM, Hernández-Damián J, and Pedraza-Chaverri J (2014) The role of PI3K/AKT/mTOR pathway in the modulation of autophagy and the clearance of protein aggregates in neurodegeneration. Cell Signal 26 2694-2701.

Hirsch FR, Varella-Garcia M, Bunn PA, Jr, Di Maria MV, Veve R, Bremmes RM, Barón AE, Zeng C, and Franklin WA (2003) Epidermal growth factor receptor in non-small-cell lung carcinomas: correlation between gene copy number and protein expression and impact on prognosis. J Clin Oncol 21:3798-3807.

Hu L, Hofmann J, and Jaffe RB (2005) Phosphatidylinositol 3-kinase mediates angiogenesis and vascular permeability associated with ovarian carcinoma. Clin Cancer Res 11:8208-8212.

Huang C, Ke Q, Costa M, and Shi X (2004) Molecular mechanisms of arsenic carcinogenesis. Mol Cell Biochem 255:57-66.

Huang C, Ma WY, Li J, Goranson A, and Dong Z (1999) Requirement of Erk, but not JNK, for arsenite-induced cell transformation. J Biol Chem 274:14595-14601.

Iadevaia V, Liu R, and Proud CG (2014) mTORC1 signaling controls multiple steps in ribosome biogenesis. Semin Cell Dev Biol 36:113-120.

Inoki $\mathrm{K}, \mathrm{Li} \mathrm{Y}$, Zhu T, Wu J, and Guan KL (2002) TSC2 is phosphorylated and inhibited by Akt and suppresses mTOR signalling. Nat Cell Biol 4:648-657.

Jacinto E, Facchinetti V, Liu D, Soto N, Wei S, Jung SY, Huang Q, Qin J, and Su B (2006) SIN1/MIP1 maintains rictor-mTOR complex integrity and regulates Akt phosphorylation and substrate specificity. Cell 127:125-137.

Jacinto E, Loewith R, Schmidt A, Lin S, Rüegg MA, Hall A, and Hall MN (2004) Mammalian TOR complex 2 controls the actin cytoskeleton and is rapamycin insensitive. Nat Cell Biol 6:1122-1128.

Jewell JL and Guan KL (2013) Nutrient signaling to mTOR and cell growth. Trends Biochem Sci 38:233-242.

Jiang BH and Liu LZ (2008) Role of mTOR in anticancer drug resistance: perspectives for improved drug treatment. Drug Resist Updat 11:63-76.

Jiang BH and Liu LZ (2009) PI3K/PTEN signaling in angiogenesis and tumorigenesis. Adv Cancer Res 102:19-65.

Jiao G, Ren T, Guo W, Ren C, and Yang K (2015) Arsenic trioxide inhibits growth of human chondrosarcoma cells through G2/M arrest and apoptosis as well as autophagy. Tumour Biol 36:3969-3977.

Jing Y, Liu LZ, Jiang Y, Zhu Y, Guo NL, Barnett J, Rojanasakul Y, Agani F, and Jiang BH (2012) Cadmium increases HIF-1 and VEGF expression through ROS, ERK, and AKT signaling pathways and induces malignant transformation of human bronchial epithelial cells. Toxicol Sci 125:10-19.

Jung DK, Bae GU, Kim YK, Han SH, Choi WS, Kang H, Seo DW, Lee HY, Cho EJ, Lee HW, et al. (2003) Hydrogen peroxide mediates arsenite activation of p70(s6k) and extracellular signal-regulated kinase. Exp Cell Res 290:144-154.

Kandoth C, McLellan MD, Vandin F, Ye K, Niu B, Lu C, Xie M, Zhang Q, McMichael JF, Wyczalkowski MA, et al. (2013) Mutational landscape and significance across 12 major cancer types. Nature 502:333-339.

Kim DH, Sarbassoy DD, Ali SM, King JE, Latek RR, Erdjument-Bromage H, Tempst $\mathrm{P}$, and Sabatini DM (2002) mTOR interacts with raptor to form a nutrient-sensitive complex that signals to the cell growth machinery. Cell 110:163-175.

Kim DH, Sarbassov DD, Ali SM, Latek RR, Guntur KV, Erdjument-Bromage H, Tempst P, and Sabatini DM (2003) GbetaL, a positive regulator of the rapamycinsensitive pathway required for the nutrient-sensitive interaction between raptor and mTOR. Mol Cell 11:895-904.

Lander HM (1997) An essential role for free radicals and derived species in signal transduction. FASEB J 11:118-124.

Lau A, Zheng Y, Tao S, Wang H, Whitman SA, White E, and Zhang DD (2013) Arsenic inhibits autophagic flux, activating the Nrf2-Keap1 pathway in a p62dependent manner. Mol Cell Biol 33:2436-2446. 
Lawrence MS, Stojanov P, Mermel CH, Robinson JT, Garraway LA, Golub TR, Meyerson M, Gabriel SB, Lander ES, and Getz G (2014) Discovery and saturation analysis of cancer genes across 21 tumour types. Nature 505:495-501.

Levine B (2007) Cell biology: autophagy and cancer. Nature 446:745-747.

Lee KM, Hwang MK, Lee DE, Lee KW, and Lee HJ (2010) Protective effect of quercetin against arsenite-induced COX-2 expression by targeting PI3K in rat liver epithelial cells. J Agric Food Chem 58:5815-5820.

Li X and Gao TY (2014) mTORC2 phosphorylates protein kinase $\mathrm{C} \zeta$ to regulate its stability and activity. Scientific Reports 15:191-198.

Li JJ, Oberley LW, Fan M, and Colburn NH (1998) Inhibition of AP-1 and NF-kappaB by manganese-containing superoxide dismutase in human breast cancer cells. FASEB $J$ 12:1713-1723.

Li L, Lu Y, Stemmer PM, and Chen F (2015) Filamin A phosphorylation by Akt promotes cell migration in response to arsenic. Oncotarget 6:12009-12019.

$\mathrm{Li} \mathrm{T}$ and Wang G (2014) Computer-aided targeting of the PI3K/Akt/mTOR pathway: toxicity reduction and therapeutic opportunities. Int J Mol Sci 15:18856-18891.

Li Y, Qu X, Qu J, Zhang Y, Liu J, Teng Y, Hu X, Hou K, and Liu Y (2009) Arsenic trioxide induces apoptosis and G2/M phase arrest by inducing Cbl to inhibit PI3K/ Akt signaling and thereby regulate p53 activation. Cancer Lett 284:208-215.

Li YM and Broome JD (1999) Arsenic targets tubulins to induce apoptosis in myeloid leukemia cells. Cancer Res 59:776-780.

Liu F and Jan KY (2000) DNA damage in arsenite- and cadmium-treated bovine aortic endothelial cells. Free Radic Biol Med 28:55-63.

Liu LZ, Jiang Y, Carpenter RL, Jing Y, Peiper SC, and Jiang BH (2011) Role and mechanism of arsenic in regulating angiogenesis. PLoS One 6:e20858.

Liu P, Begley M, Michowski W, Inuzuka H, Ginzberg M, Gao D, Tsou P, Gan W, Papa A, Kim BM, et al. (2014) Cell-cycle-regulated activation of Akt kinase by phosphorylation at its carboxyl terminus. Nature 508:541-545.

Lynn S, Gurr JR, Lai HT, and Jan KY (2000) NADH oxidase activation is involved in arsenite-induced oxidative DNA damage in human vascular smooth muscle cells. Circ Res 86:514-519.

Ma XM and Blenis J (2009) Molecular mechanisms of mTOR-mediated translational control. Nat Rev Mol Cell Biol 10:307-318.

Ma ZB, Xu HY, Jiang M, Yang YL, Liu LX, and Li Y-H (2014) Arsenic trioxide induces apoptosis of human gastrointestinal cancer cells. World $J$ Gastroenterol 20: $5505-5510$

Magnuson B, Ekim B, and Fingar DC (2012) Regulation and function of ribosomal protein S6 kinase (S6K) within mTOR signalling networks. Biochem J 441:1-21.

Mann KK, Colombo M, and Miller WH, Jr (2008) Arsenic trioxide decreases AKT protein in a caspase-dependent manner. Mol Cancer Ther 7:1680-1687.

Manning BD and Cantley LC (2007) AKT/PKB signaling: navigating downstream. Cell 129:1261-1274.

Manning BD, Tee AR, Logsdon MN, Blenis J, and Cantley LC (2002) Identification of the tuberous sclerosis complex-2 tumor suppressor gene product tuberin as a target of the phosphoinositide 3-kinase/akt pathway. Mol Cell 10:151-162.

Manning BD and Toker A (2017) AKT/PKB signaling: navigating the network. Cell 169:381-405.

Meng D, Frank AR, and Jewell JL (2018) mTOR signaling in stem and progenitor cells. Development 145:dev152595.

Michailidi C, Hayashi M, Datta S, Sen T, Zenner K, Oladeru O, Brait M, Izumchenko $\mathrm{E}$, Baras A, VandenBussche C, et al. (2015) Involvement of epigenetics and EMTrelated miRNA in arsenic-induced neoplastic transformation and their potential clinical use. Cancer Prev Res (Phila) 8:208-221.

Moon K, Guallar E, and Navas-Acien A (2012) Arsenic exposure and cardiovascular disease: an updated systematic review. Curr Atheroscler Rep 14:542-555.

Mu FT, Callaghan JM, Steele-Mortimer O, Stenmark H, Parton RG, Campbell PL, McCluskey J, Yeo JP, Tock EP, and Toh BH (1995) EEA1, an early endosomeassociated protein. EEA1 is a conserved alpha-helical peripheral membrane protein flanked by cysteine "fingers" and contains a calmodulin-binding IQ motif. $J$ Biol Chem 270:13503-13511.

Nagappan A, Lee WS, Yun JW, Liu JN, Chang S, Jeong J, Kim GS, Jung J, and Hong S (2017) Tetraarsenic hexoxide induces G2/M arrest, apoptosis, and autophagy via PI3K/AKT suppression and p38 MAPK activation in SW620 human colon cancer cells. PLoS One 12:E0174591-E0174591.

Naujokas MF, Anderson B, Ahsan H, Aposhian HV, Graziano JH, Thompson C, and Suk WA (2013) The broad scope of health effects from chronic arsenic exposure: update on a worldwide public health problem. Environ Health Perspect 121:295-302. Ouyang W, Li J, Ma Q, and Huang C (2006) Essential roles of PI-3K/Akt/IKKbeta/ NFkappaB pathway in cyclin D1 induction by arsenite in JB6 Cl41 cells. Carcinogenesis 27:864-873.

Patrucco E, Notte A, Barberis L, Selvetella G, Maffei A, Brancaccio M, Marengo S, Russo G, Azzolino O, Rybalkin SD, et al. (2004) PI3Kgamma modulates the cardiac response to chronic pressure overload by distinct kinase-dependent and -independent effects. Cell 118:375-387.

Pearce LR, Huang X, Boudeau J, Pawłowski R, Wullschleger S, Deak M, Ibrahim AF, Gourlay R, Magnuson MA, and Alessi DR (2007) Identification of Protor as a novel Rictor-binding component of mTOR complex-2. Biochem $J$ 405:513-522.

Peterson TR, Laplante M, Thoreen CC, Sancak Y, Kang SA, Kuehl WM, Gray NS, and Sabatini DM (2009) DEPTOR is an mTOR inhibitor frequently overexpressed in multiple myeloma cells and required for their survival. Cell 137:873-886.

Porta C, Paglino C, and Mosca A (2014) Targeting PI3K/Akt/mTOR signaling in cancer. Front Oncol 4:64

Rad E, Murray JT, and Tee AR (2018) Oncogenic signaling through mechanistic target of rapamycin (mTOR): a driver of metabolic transformation and cancer progression. Cancer (Basel) 10:5.

Rameh LE and Cantley LC (1999) The role of phosphoinositide 3-kinase lipid products in cell function. $J$ Biol Chem 274:8347-8350.

Rauch J, Kolch W, and Mahmoudi M (2012) Cell type-specific activation of AKT and ERK signaling pathways by small negatively-charged magnetic nanoparticles. Sci Rep 2:868
Redondo-Muñoz J, Escobar-Díaz E, Hernández Del Cerro M, Pandiella A, Terol MJ, García-Marco JA, and García-Pardo A (2010) Induction of B-chronic lymphocytic leukemia cell apoptosis by arsenic trioxide involves suppression of the phosphoinositide 3-kinase/Akt survival pathway via c-jun-NH2 terminal kinase activation and PTEN upregulation. Clin Cancer Res 16:4382-4391.

Rossman TG, Stone D, Molina M, and Troll W (1980) Absence of arsenite mutagenicity in E coli and Chinese hamster cells. Environ Mutagen 2:371-379.

Roy R, Singh SK, Chauhan LK, Das M, Tripathi A, and Dwivedi PD (2014) Zinc oxide nanoparticles induce apoptosis by enhancement of autophagy via PI3K/Akt/mTOR inhibition. Toxicol Lett 227:29-40.

Samuels Y, Wang Z, Bardelli A, Silliman N, Ptak J, Szabo S, Yan H, Gazdar A, Powell SM, Riggins GJ, et al. (2004) High frequency of mutations of the PIK3CA gene in human cancers. Science 304:554.

Sancak Y, Thoreen CC, Peterson TR, Lindquist RA, Kang SA, Spooner E, Carr SA, and Sabatini DM (2007) PRAS40 is an insulin-regulated inhibitor of the mTORC1 protein kinase. $\mathrm{Mol}$ Cell 25:903-915.

Sarbassov DD, Ali SM, Kim DH, Guertin DA, Latek RR, Erdjument-Bromage H, Tempst P, and Sabatini DM (2004) Rictor, a novel binding partner of mTOR, defines a rapamycin-insensitive and raptor-independent pathway that regulates the cytoskeleton. Curr Biol 14:1296-1302.

Saxton RA and Sabatini DM (2017) mTOR signaling in growth, metabolism, and disease. Cell 168:960-976.

Schroder WA, Buck M, Cloonan N, Hancock JF, Suhrbier A, Sculley T, and Bushell G (2007) Human Sin1 contains Ras-binding and pleckstrin homology domains and suppresses Ras signalling. Cell Signal 19:1279-1289.

Sen CK and Packer L (1996) Antioxidant and redox regulation of gene transcription. FASEB J 10:709-720.

Seshacharyulu P, Ponnusamy MP, Haridas D, Jain M, Ganti AK, and Batra SK (2012) Targeting the EGFR signaling pathway in cancer therapy. Expert Opin Ther Targets 16:15-31.

Shankar S, Shanker U, and Shikha (2014) Arsenic contamination of groundwater: a review of sources, prevalence, health risks, and strategies for mitigation. Sci World $J$ 2014:304524.

Simeonova PP, Wang S, Hulderman T, and Luster MI (2002) c-Src-dependent activation of the epidermal growth factor receptor and mitogen-activated protein kinase pathway by arsenic. Role in carcinogenesis. J Biol Chem 277: 2945-2950.

Skinner HD, Zhong XS, Gao N, Shi X, and Jiang BH (2004) Arsenite induces p70S6K1 activation and HIF-1alpha expression in prostate cancer cells. Mol Cell Biochem 255:19-23.

Snow ET (1992) Metal carcinogenesis: mechanistic implications. Pharmacol Ther $\mathbf{5 3}$ $31-65$.

Stenmark H, Aasland R, Toh BH, and D'Arrigo A (1996) Endosomal localization of the autoantigen EEA1 is mediated by a zinc-binding FYVE finger. $J$ Biol Chem 271:24048-24054.

Stevens JJ, Graham B, Dugo E, Berhaneselassie-Sumner B, Ndebele K, and Tchounwou PB (2017) Arsenic trioxide induces apoptosis via specific signaling pathways in HT-29 colon cancer cells. J Cancer Sci Ther 9:298-306.

Suzuki S, Dobashi Y, Sakurai H, Nishikawa K, Hanawa M, and Ooi A (2005) Protein overexpression and gene amplification of epidermal growth factor receptor in nonsmall cell lung carcinomas: an immunohistochemical and fluorescence in situ hybridization study. Cancer 103:1265-1273.

Tai S, Xu L, Xu M, Zhang L, Zhang Y, Zhang K, Zhang L, and Liang C (2017) Combination of arsenic trioxide and Everolimus (Rad001) synergistically induces both autophagy and apoptosis in prostate cancer cells. Oncotarget 8:11206-11218.

Taniguchi CM, Kondo T, Sajan M, Luo J, Bronson R, Asano T, Farese R, Cantley LC, and Kahn CR (2006) Divergent regulation of hepatic glucose and lipid metabolism by phosphoinositide 3-kinase via Akt and PKClambda/zeta. Cell Metab 3:343-353. Thomanetz V, Angliker N, Cloëtta D, Lustenberger RM, Schweighauser M, Oliveri F, Suzuki N, and Rüegg MA (2013) Ablation of the mTORC2 component rictor in brain or Purkinje cells affects size and neuron morphology. J Cell Biol 201: $293-308$

Valvezan AJ, Turner M, Belaid A, Lam HC, Miller SK, McNamara MC, Baglini C, Housden BE, Perrimon N, Kwiatkowski DJ, et al. (2017) mTORC1 couples nucleotide synthesis to nucleotide demand resulting in a targetable metabolic vulnerability. Cancer Cell 32:624-638.e5.

Vander Haar E, Lee SI, Bandhakavi S, Griffin TJ, and Kim DH (2007) Insulin signalling to mTOR mediated by the Akt/PKB substrate PRAS40. Nat Cell Biol 9: 316-323.

Wang CY, Mayo MW, and Baldwin AS, Jr (1996) TNF- and cancer therapy-induced apoptosis: potentiation by inhibition of NF-kappaB. Science 274:784-787.

Wang G (2013) Analysis of Complex Diseases: A Mathematical Perspective, CRC Press, Boca Raton, FL

Wang G, Zhang T, Sun W, Wang H, Yin F, Wang Z, Zuo D, Sun M, Zhou Z, Lin B, et al. (2017) Arsenic sulfide induces apoptosis and autophagy through the activation of ROS/JNK and suppression of Akt/mTOR signaling pathways in osteosarcoma. Free Radic Biol Med 106:24-37.

Wang L, Harris TE, Roth RA, and Lawrence JC, Jr (2007) PRAS40 regulates mTORC1 kinase activity by functioning as a direct inhibitor of substrate binding. $J$ Biol Chem 6:282.

Wang L, Jiang H, Yin Z, Aschner M, and Cai J (2009) Methylmercury toxicity and Nrf2-dependent detoxification in astrocytes. Toxicol Sci 107:135-143.

Wang Y, Yin D, Xu C, Wang K, Zheng L, and Zhang Y (2016) Roxarsone induces angiogenesis via PI3K/Akt signaling. Cell Biosci 6:54

Wang X and Proud CG (1997) p70 S6 kinase is activated by sodium arsenite in adult rat cardiomyocytes: roles for phosphatidylinositol 3-kinase and p38 MAP kinase. Biochem Biophys Res Commun 238:207-212.

Wang Z, Yang J, Fisher T, Xiao H, Jiang Y, and Yang C (2012) Akt activation is responsible for enhanced migratory and invasive behavior of arsenic-transformed human bronchial epithelial cells. Environ Health Perspect 120:92-97. 
Wen G, Hong M, Calaf GM, Roy D, Partridge MA, Li B, and Hei TK (2010) Phosphoproteomic profiling of arsenite-treated human small airway epithelial cells. Oncol Rep 23:405-412.

West KA, Brognard J, Clark AS, Linnoila IR, Yang X, Swain SM, Harris C, Belinsky S, and Dennis PA (2003) Rapid Akt activation by nicotine and a tobacco carcinogen modulates the phenotype of normal human airway epithelial cells. $J$ Clin Invest 111:81-90.

Wu XN, Wang XK, Wu SQ, Lu J, Zheng M, Wang YH, Zhou H, Zhang H, and Han J (2011) Phosphorylation of Raptor by p38beta participates in arsenite-induced mammalian target of rapamycin complex 1 (mTORC1) activation. J Biol Chem $\mathbf{2 8 6}$ 31501-31511.

Xia C, Meng Q, Cao Z, Shi X, and Jiang BH (2006) Regulation of angiogenesis and tumor growth by p110 alpha and AKT1 via VEGF expression. J Cell Physiol 209 56-66.

Xue G, Restuccia DF, Lan Q, Hynx D, Dirnhofer S, Hess D, Rüegg C, and Hemmings BA (2012) Akt/PKB-mediated phosphorylation of Twist1 promotes tumor metastasis via mediating cross-talk between PI3K/Akt and TGF- $\beta$ signaling axes. Cancer Discov 2:248-259.

Xue P, Hou Y, Zhang Q, Woods CG, Yarborough K, Liu H, Sun G, Andersen ME, and $\mathrm{Pi} J$ (2011) Prolonged inorganic arsenite exposure suppresses insulinstimulated AKT S473 phosphorylation and glucose uptake in 3T3-L1 adipocytes: involvement of the adaptive antioxidant response. Biochem Biophys Res Commun 407:360-365.

Yang Q, Inoki K, Ikenoue T, and Guan KL (2006) Identification of Sin1 as an essential TORC2 component required for complex formation and kinase activity. Genes Dev 20:2820-2832.
Yecies JL, Zhang HH, Menon S, Liu S, Yecies D, Lipovsky AI, Gorgun C, Kwiatkowski DJ, Hotamisligil GS, Lee CH, et al. (2011) Akt stimulates hepatic SREBP1c and lipogenesis through parallel mTORC1-dependent and independent pathways. Cell Metab 14:21-32.

Yoon P, Giafis N, Smith J, Mears H, Katsoulidis E, Sassano A, Altman J, Redig AJ, Tallman MS, and Platanias LC (2006) Activation of mammalian target of rapamycin and the p70 S6 kinase by arsenic trioxide in BCR-ABL-expressing cells. Mol Cancer Ther 5:2815-2823.

You D, Kim Y, Jang MJ, Lee C, Jeong IG, Cho YM, Hwang JJ, Hong JH, Ahn H, and Kim CS (2015) KML001 induces apoptosis and autophagic cell death in prostate cancer cells via oxidative stress pathway. PLoS One 10:e137589.

Zhang Y, Bhatia D, Xia H, Castranova V, Shi X, and Chen F (2006) Nucleolin links to arsenic-induced stabilization of GADD45alpha mRNA. Nucleic Acids Res 34: 485-495.

Zhang Y, Wei Z, Liu W, Wang J, He X, Huang H, Zhang J, and Yang Z (2017) Melatonin protects against arsenic trioxide-induced liver injury by the upregulation of Nrf2 expression through the activation of PI3K/AKT pathway. Oncotarget 8: $3773-3780$.

Zhao L and Vogt PK (2008) Class I PI3K in oncogenic cellular transformation. Oncogene 27:5486-5496.

Address correspondence to: Max Costa, Department of Environmental Medicine, New York University School of Medicine, 57 Old Forge, Tuxedo, NY 10987. E-mail: Max.Costa@nyumc.org 